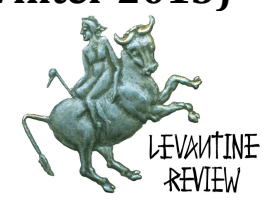

\title{
THE CURRENT SYRIAN POPULAR VIEW OF THE JEWS
}

\author{
Alejandra Álvarez Suárez* \\ Francisco del Río Sánchez**
}

\begin{abstract}
The remaining small Jewish communities of Syria run the risk of disappearing completely due to the marginalization suffered as a consequence of the political situation since 1948. The Eli Cohen affair (1965,) the Six-Day War (1967,) and the Yom Kippur War (1973) made the Baathist authorities of the country consider definitively the Syrian Jews as suspected Zionists or Zionist sympathizers. Nevertheless, in Syrian popular perceptions, the view of the Jews and Judaism did not always coincide with the ideology and propaganda emanating from the regime. In fact it is very interesting to note how good memories of times past, about an erstwhile coexistence with members of the Jewish community, still survive among many Syrians, both Muslims and Christians, belonging to the so-called "urban middle class." This paper evaluates some examples, in the forms of anecdotes, popular sayings and proverbs, dealing with the Jews, and popularized in Syrian colloquialisms, in order to reveal some of the popular views of Judaism and Jews within Syrian society.
\end{abstract}

The different religious communities of Syria (Arabic tawa'if) form a mosaic so heterogeneous and diverse that, in a predominantly Muslim context, this situation can easily pass unnoticed for the Western observer. This diversity tends to get confused in the middle of a cultural context common to all members of that society, which, with some exceptions, speak the same language and share common folk, culinary and artistic traditions. The rich religious diversity of Syria has come to bewilder even the different powers that have, in succession, come to rule that territory ${ }^{1}$.

On the one hand we find the Muslim communities of Syria demarcated as follows:

1) Sunnis,

2) Shiis ja'faris,

3) Alawites,

4) Ismailis.

5) Druzes. Although deemed in turn as Muslims and non-Muslims, depending on the observer, the Druzes of Syria are considered Muslims from a legal point of view.

Traditionally (almost from the years of the French Mandate) have shared with Syria's

\footnotetext{
${ }_{1}$ Project FFI2011-25460/FILO. See Bruce Masters, Christians and Jews in the Ottoman Arabic Word: The Roots of Sectarianism (Cambridge: Cambridge University Press 2001), 65.
} 


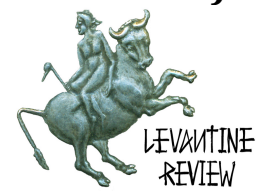

Muslim communities the same Law of Personal Status ${ }^{2}$ with some concessions given to their specificity. ${ }^{3}$

Concomitant to the Muslim-defined communities, there Christian churches in Syria, each with its own statute:

6) Orthodox Rum, of the Byzantine tradition

7) Catholic Rum, of Byzantine tradition,

8) Maronites,

9) Traditional Western Syriacs or Jacobites,

10) Catholic Western Syriacs,

11) Chaldaeans or Catholic Eastern Syriacs,

12) Assyrians, also called Traditional Eastern Syriacs or Nestorians (all these of Syriac tradition),

13) Orthodox Armenians,

14) Catholic Armenians,

15) Protestant Armenians,

16) Latin Catholics (or Western rite Catholics,)

17) The different Protestant churches.

There are also a couple of groups without legal recognition and Personal Status in Syria: 18) The Jehowah's Witnesses (Shuhud Yahwah,) officially forbidden in the country since 1964 on suspicion of Zionist sympathies. This circumstance has prevented their growth. Thanks to a tacit concession, the few members of this congregation with Syrian citizenship can meet privately to celebrate their religious services.

19) Also the Yazidis (al-yazidiyyun,) known colloquially in Syria as the "Servants of Satan" (a'bad Shaytan,) are a community very distant from its Islamic origins with many syncretic elements. The Yazidis are Kurds from the region of Afrin (North of Aleppo) and the Jazeera ${ }^{4}$. Currently they don't have any official recognition in Syria: they are officially treated as Muslims (as far as the Law of Personal Status is concerned,) and often live in a legal limbo inside the Syrian Arab Republic. On April 8, 2011, and as a consequence of the popular protests that began in 2011, Bashar al-Asad announced a new reform package, parts of which proposes granting Syrian citizenship to Yazidi Kurds.

20) Last but not least, there are some Jews still living in Syria.

2 This list of Muslim communities in Syria is the official one from the French Mandate to the present: See Journal Officiel de la République Syrienne X/13-3-1936, Arrêté no. 61/L. R. 65, annexe 1, and Qawanin al-ahwal as-shakhsiyya lit-tawa'if al-urthuduksiyya walkathulikiyya wal-injiliyya wal-arman was-suriyan wal-musawiyyin (Damascus: Qassab Hasan, without date), 18.

3 See Qanun al-ahwal ash-shakhsiyya (Damascus: An-Nuri foundation 2008), 93.

${ }^{4}$ Roger Lescot, Les Yezidis de Syrie et du Djebel Sindjar (Beirut: Librairie du Liban 1975), 199-217; Kerim Yildiz, The Kurds in Syria. The Forgotten People, London: Pluto Press 2005, 9-10 and 24. 


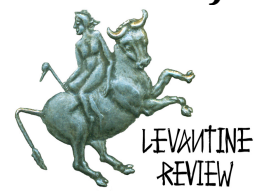

\section{JUDAISM IN SYRIA}

Ironically, it is Judaism, arguably Syria's oldest confessional group, that is the faith with the least number of followers - a situation owed at least partially to the marginalization that the Jewish community has suffered as a result of the political situation created after 1948.

It is not within the scope of this paper to get tangled up in the origins of Judaism in Syria; a history that is lost in the legends epically linking the first Jewish settlements in the country to the rule of King David, which extended into present-day Syria. ${ }^{5}$ At any rate, it is certain than in the Helenistic Age (third to first Centuries BCE) the Jews were numerous in Syria and were rooted in that territory, and this situation continued during the Roman period. In fact, the proximity to Eretz Israel entailed that the Syrian Jews had the same halakhot or religious precepts as the Jews living in Palestine (we may remember the text of the Mishnah asserting that one who buys a field in Syria is as one who buys a field in the outskirts of Jerusalem) ${ }^{6}$.

After the Islamic conquest of the seventh century, the Jews of Bilad ash-Sham (as the area began being referred to in Arabic usage,) significantly less numerous than those of Iraq, settled themselves around the large urban centers: in Syria there is a clear population growth inside the Jewish quarters of Aleppo, Damascus, Homs and Hama, cities with Jewish population from the Greco-Roman era. The Jews were accustomed to adapting themselves to the political vicissitudes that were taking place in the zone, and they easily accepted the Muslim-Arabic power. The new rulers provided them protection and allowed them to establish economic and cultural communication between the different Jewish communities thanks to the establishment of a single political power in the area, something that had been impossible in the past.

Regarding the Islamization of non-Muslims, understanding it as the assimilation of culture that accompanied Islam, it did not necessarily mean adopting the religion of the new rulers, i.e. conversion to Islam, but rather the acceptance of the elements of that civilization, such as social organization, literature, clothing, food or the dominant language, Arabic. This cultural Islamization allows us to understand some characteristics of the non-Muslim communities of these lands. In fact, their organization in tawa'if (or confessions/communities) responds to this acceptance of the Islamic culture. The level of assimilation into the ruling culture became so intense that non-Muslims were almost indistinguishable from their Muslim neighbors except for their religion. In the territories of Syria, that cultural Islamization resulted in progressive arabization of the non-Arab populations. The arabization (that is, the adoption of the Arabic language as the common vehicle of communication,) became fundamental to the unification of Jewish

\footnotetext{
5 See 2Samuel 8, 1-12; Psalms 60; 2Walter P. Zenner, A Global Community: The Jews from Aleppo, Syria (Detroit: Wayne State University Press 2000), 33.

${ }^{6}$ Ha-qoneh b-suriya kha-qoneh ba-parvar she-birushalayim (Zera'im: Hallah 4, 11).
} 


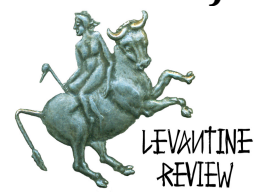

communities. In fact, the Arabic language was an essential cultural aspect for Syrian Jews in urban environments. ${ }^{7}$

\section{HETEROGENEITY OF THE SYRIAN JEWS}

The arrival of Islam gave some cultural unity to the Jews. But, it is also true that every qehillah (community) belonging to a concrete town developed differently from the others. The urban native Jews, those who lived there from the beginning of the Islamic rule, were known as the "Arabized" (musta'rabun); so were the Jews who arrived in Ottoman Syria during the sixteenth century. ${ }^{8}$. Amongst them there were also Karaites (a Jewish minority considered heretic by their coreligionists) in Damascus between the seventh and sixteenth centuries. In the Eastern Kurdish mountains there were also Jews, but they were very different from those living in the urban environments. They spoke Kurdish or Aramaic and, although they were not organized in tribes as their Muslim or Nestorian neighbors, they were fully integrated in that area. The Kurdish Jews maintained a strong Jewish identity, but they were considered marginal by the urban Jews ${ }^{9}$.

The Sephardic Jews appeared in the Ottoman Empire after the Expulsion of 1492, and they were well received by the Sultan, who even signed Firmans to ensure their protection. ${ }^{10}$ In the Arabic provinces, they formed important communities in Aleppo, Damascus and Jerusalem. In Aleppo, the Sephardic community was so large that they even conserved Ladino as a spoken language until the twentieth century. ${ }^{11}$ Jews coming from Italy or France arrived to this city attracted by the commercial possibilities. These "señores francos" benefited from their knowledge of European languages, their Western education, and their foreign status: this last attribute allowed them to enjoy the diplomatic protection afforded representatives of European states.

\footnotetext{
${ }^{7}$ In this point it is important to remember that Zionism and Arab Nationalism have effaced this reality. They both avoid speaking of 'Arab Jews'. The Zionists considered that 'Arab' and 'Jew' were incompatible concepts and they created the word mizrahi ("Oriental") to name the Jews coming from the Arabic or Levantine countries. The Syrian Arab nationalist language uses the adjetive musawi ("follower of Moses") to refer to the Jews, avoiding the word "Jew". They are simply "Arabs followers of the Jewish religion". See Qawanin al-ahwal ash-shakhsiyya lit-tawa'if al-urthuduksiyya wal-kathulikiyya walinjiliyya wal-arman was-suriyan wal-musawiyyin, 389. The word musawi probably comes from the Turkish-Ottoman administrative language, were we find the expression musevi olander. See, Kemal Karpat, Studies on Ottoman social and political story: selected articles and essays (Leiden: Brill 2002), 153.

${ }^{8}$ Avigdor Levy, The Jews of the Ottoman Empire (Princeton: Darwin Press 1994), 42-70.

${ }^{9}$ See Bruce Masters, Christians and Jews in the Ottoman Arabic Word, 48.

10 See Norman A. Stillman, The Jews of Arab Lands. A History and Source Book, (Philadelphia: The Jewish Publication Society of America 1979), 87-88.

11 See Mahmud al-Haritani, Tarikh al-yahud fi-Halab (Aleppo: Ray 2008), 172, 175.
} 


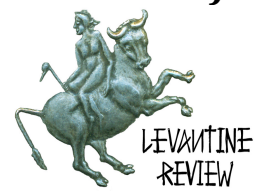

\section{DECLINE OF JEWISH PRESENCE IN SYRIA}

There are two reasons for the decline of the Jewish presence in Syria. In chronological order, the first one is economic and it is related to the decline of commerce in the cities, specially Aleppo, since the mid-nineteenth century. The second reason is political, and is related to the events taking place subsequent to the independence of Syria (1946,) the creation of the State of Israel (1948,) and the successive conflicts with this southern neighbor during the Baathist era.

The study of the Jewish presence in the Near East during the second half of the nineteenth century has focused primarily on the important and observable increase of the Jewish population in Palestine. ${ }^{12}$ Many Jews arrived into major cities of Ottoman Palestine, and this fact provoked a significant increase in Jewish population in these urban centers. ${ }^{13}$ However, this trend contrasts with what happened in the Syrian territories during this same period: in this area, there was a progressive emigration of Jews to other Ottoman territories, to Europe (especially Britain), to South America and the United States, all arguably as a result of commercial declines suffered by the Ottoman Levantine cities. ${ }^{14}$

This economic decline dates back to the early nineteenth century. During those years a series of political and economic setbacks damaged the traditional trading system. In the late nineteenth and early twentieth centuries, the Syrian trade was invaded by British manufactures, so that many Jewish entrepreneurs migrated to more prosperous lands. The arrival of the French Mandate also constituted a blow to the traditional structure of Levantine trade and produced new migrations of Jews who were not particularly enthralled with the new borders that drowned the commercial routes which had served as trade arteries since ancient times.

\section{THE FINAL BLOW}

The Jewish resettlement in Palestine and the success of Western anti-Jewish propaganda within Arabic-speaking Levantine environments ${ }^{15}$ were two triggers for a policy that would lead to the virtual disappearance of the Jewish population in Syria.

After the Syrian Declaration of Independence in April 1946, the events related to the foundation of the state of Israel in 1948 triggered a wave of violence against the Syrian Jews. In just a decade, this small population of only about fifteen thousand members

\footnotetext{
12 It was caused by the waves of Jewish immigrants coming from the Ottoman territories annexed by the Western powers, and the Jews that arrived from the Russian Empire and Central Europe.

${ }^{13}$ See Kemal Karpat, Studies on Ottoman social and political story: selected articles and essays, 146-150.

14 Walter P. Zenner, A Global Community: The Jews from Aleppo, Syria, 51-62.

15 The first anti-Semitic treatises in Arabic were translated from French by Maronites and other Uniate Christians during the 19th Century. The Protocols of the Elders of Zion have been edited in many occasions (the first one in Cairo, the year 1927).
} 


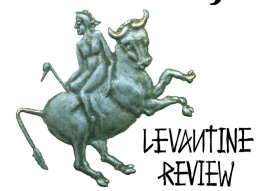

declined through immigration by sixty percent. Legal measures instated against the Jews beginning in 1948 included freezing of accounts and even confiscation of properties.

The Eli Cohen spying affair (1965,) and the Six Days War (1967,) caused further reprisals and attacks against Jews and Jewish properties in Aleppo, Damascus and Qamishli. ${ }^{16}$ In 1968 there were about 4.000 Jews in Syria, mainly in Aleppo (about 1.200,) and Damascus (about 2.500,) almost all of them belonging to the middle and lower class. ${ }^{17}$

After the Yom Kippur War (1973,) the Syrian Jewish community remained isolated from the outside world. In the 1980s there were no more than 1,400 Jews left in Syria. The 1990 s witnessed the last great Syrian Jewish emigration, especially to the United States and Israel. Currently it is impossible to verify how many Jews remain in Syria. Even the paltry number of 250 Jews (2005,) which is often used officially, may be exaggerated: in fact, only six Jews live today in Aleppo in the neighborhood of Gdeydeh. All the Jewish properties in Syria are administered by a representative of the community of Damascus, the only one left in the whole country. ${ }^{18}$

\section{JUDAISM AND JEWS IN THE SYRIAN COLLECTIVE IMAGINATION}

It is well known that one pillar of the political rhetoric of the Syrian ruling elite is the encouragement and promotion of anti-Israeli sentiments. It is exposed in the Preamble of the Constitution promulgated by Hafiz al-Asad in 1973 and timidly reformed during the years 1980, 2000 and 2012:

The march toward the establishment of a socialist order besides being a necessity stemming from the Arab society's needs, is also a fundamental necessity for mobilizing the potentialities of the Arab masses in their battle with Zionism and imperialism. ${ }^{19}$

This idea still appears in the new text of 2012:

16 In this last city, the few Jews that remained (about 300) didn't have problems with the Kurds.

17 See Maurice A. Roumani, "The Case of the Jews from Arab Countries: A Neglected Issue", Willem A. Veenhoven, Case Studies on Human Rights and Fundamental Freedoms. A Word Survey, Volume 5 (The Hague: Martinus Nijhoff 1976), 72-78.

18 The Jewish historiography has placed too much emphasis on the 'dark side' of Jews' life in the midst of Arab societies after the creation of the State of Israel. It has presented their suffering as the result of a long history of anti-Semitism and intolerance, a 'pretended' feature of the Muslim societies. See Bruce Masters, Christians and Jews in the Ottoman Arabic Word, 4 and Bat Ye'or (Gisèle Littman), Les Chrétientés d'Orient entre Jihad et dhimmitude, $\mathrm{VII}^{e}$-XX ${ }^{e}$ siècles (París: Le Cerf 1991).

${ }^{19}$ Arabic text in: Dustur al-Jumhuriyya al-'Arabiyya as-Suriyya as-Sadir bil-marsum raqm 208, tarikh 13/03 (Damascus: Dar as-Safadi 2007), 5-6. 


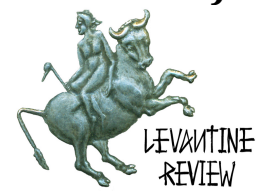

Syria also gained crucial political importance as the heart of the Arab world and the confrontation frontline with the Zionist enemy.

This institutional anti-Zionism has its roots in the early days of Arab Nationalism, and may even be traced back to the pre-Mandate period. However, during the Baathist era, it has continued to be used by the regime for propaganda purposes. ${ }^{20}$ On many occasions, the ideological development of Syrian anti-Zionism has ended up confusing Zionism and Judaism (a fact unfortunately very common not only in the Arab countries but also in Israel proper.)

For this reason, speaking in Syria about Israel or Judaism has been considered a topic of conversation to avoid. The question of Israel and, by extension, the Jews and Judaism forms a part of what is known as the "Forbidden Trinity" (ath-thaluth al-muharram,) a popular expression that was coined by the Syrian writer Bu Ali al-Yasin (d. 2000) to name the questions officially taboo in conversations inside Baathist Syria-that is to say, religion, sexuality, and politics. ${ }^{21}$

Publically speaking about Jews is considered something suspicious, meaning that the Syrian citizen (and even more so the ajnabi, the foreigner from outside the country) should not show too much interest in the questions related, for example, to Jewish properties (Synagogues or private buildings) or the number and identity of Jewish inhabitants living in certain towns. We may remember incidents like the Eli Cohen affair (1961-1965,) the question of the Aleppo Codex (1958,) or the Israeli bombings against Syrian positions in recent years: all them have heightened the regime's suspicions vis-àvis of those who may show some interest in Jews and Judaism inside Syria.

\section{PROPAGANDA AND POPULAR IMAGINATION}

In this context it is important to stress that, in many cases, the official propaganda doesn't fit with the sentiment and the perception of the Syrian population. As has been pointed out, the emigration of the majority of Syrian Jews implied that, with the passing of time, the memory of coexistence has been gradually erased giving way to a stereotype supported by popular sayings, proverbs and topics very similar to what happens inside other countries in which the Jewish population disappeared. This is, for instance, the

20 The first official Anti-Zionist declaration was pronounced in the Arab Congress of 1919. About the public opinion on Zionism in Syria after the end of the First World War, read the results of the report performed by Henry Church King and Charles R. Crane in 1919, in "King-Crane report on the Near East", Editor and Publisher Company 55, number 27, Section 2 (2 December 1922): I, The geography of the claims, III §3. Philip S. Khouri, Syria and the French Mandate. The Politics of the Arab Nationalism, 1920-1945

(Princeton: Princeton Univ. Press 1987), 121-122.

${ }^{21} \mathrm{Bu}$ Ali Yasin, Ath-Thaluth al-Muharram: Dirasat fi l-jins wad-din was-sirac at-tabaqi

(Beirut: Dar at-Tali'a lit-taba'a wan-nashar 1983). 


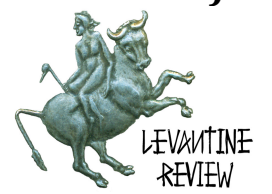

case in Spain where, after the Expulsions of 1492, the image of the Jew was reconfigured from popular clichés, most of which have survived to this day. ${ }^{22}$

For this reason, a good way of showing the Syrian popular opinions of Jews is to analyze the sayings, proverbs and anecdotes involving Jews, and which are still current in many popular contexts. In what follows, we do not claim to show all the existing examples; rather, we offer a small representative sampling of them, hopefully summarizing the general Syrian mental image of the Jews. Many examples come from Aleppo: this circumstance may be an advantage, because this city continues to represent the most paradigmatic model of a Syrian city in which the Ottoman heritage coexists alongside modernity. Without a doubt, and within the larger Middle Eastern context, Aleppo remains a typically Muslim city, ${ }^{23}$ albeit one that is heterogeneous from a social and religious point of view. This diversity is one of Aleppo's distinctive features and it contrasts with the increasingly homogeneous panorama that emerges from other Arabdefined or "Muslim" towns.

A typical feature of Aleppo resides in its traditionalism in the conservation of the social structure, which makes it a model of a Muslim "mosaic" society. ${ }^{24}$ On the other hand, the character of Aleppo competes with Damascus in the sense of humour (sometimes very strongly-worded, daring and impudent,) a fact that contrasts with the self-affirmed gravity and seriousness with which the Aleppines describe themselves: that their character is characterised by these qualities (Halab jurat al-hamm, Aleppo, the hole of sorrows, as goes the local saying. $)^{25}$

\section{JEWS AND ARMENIANS}

The Syrians used to say that Armenians, a community well represented in the country and specially inside the city of Aleppo, are like "Jews amongst the Christians" (il-yahud min in-nasara,) a meaningful expression very useful to frame some ideas that will be discussed below. Beside this, it is not strange to hear Christians saying another curious expression when they enumerate the religious groups (tawa'if) of Syria. They reduce the complicated mosaic to three simple factions: "Muslims, Christians and Armenians" (Islam, Msihiyye u-Arman) ${ }^{26}$.

\footnotetext{
${ }^{22}$ Gonzalo Álvarez Chillida, El Antisemitismo en España. La imagen del judío (1812-2002). Madrid: Marcial Pons 2002, 62-68.

${ }^{23}$ André Raymond, "Ville Musulmane, ville arabe: mythes orientalistes et recherches récentes", Jean-Louis Biget and Claude Jean-Hervé, eds. Panoramas urbains. Situation de l'histoire des villes, (Fontenay-Saint-Cloud: ENS Editions 1995), 309-336.

${ }^{24}$ Ira M. Lapidus, "The Early Evolution of Muslim Urban Society", Comparative Studies in Society and History 15 (1973), 21-50.

25 Muhammad Khayr ad-Din al-Asadi, Mawsucat Halab al-Muqarana, 7 vol. (Aleppo:

Ma'had at-turath al-'ilmi al-'arabi 1981-1988), III, 103.

26 The Muslims say also: 'Muslims, Kurds, Christians and Armenians' (Islam, Akrad, Msihieh u-Arman)!.
} 


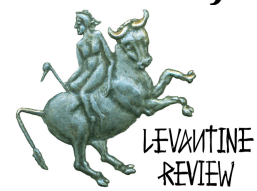

At this point, we should analyze the cause of this assimilation, in the Syrian mentality, of the Armenians with the Jews (il-yahud min in-nasara.) We suggest that this attitude may be due to four main reasons:

1) Armenians and Jews constitute a human group clearly differentiated in the social melting-pot of Syria.

2) They both have a strong group-consciousness. In the case of the Armenians this is maintained thanks to preservation of the identity through endogamy, use of traditional language (specially amongst the Armenian Orthodox,) ${ }^{27}$ and the religious cohesion around a type of Pre-Chalcedonianism that keeps them apart from the other Christian communities.

3) Like Jews, Armenians continue to promote in Syria a "culture of the exile" through the creation and maintenance of social structures for their people (from schools and social or sports clubs to committees for the advocacy of the Armenian cause or political parties only for Armenians.) The last aim of these institutions is to preserve a distinct identity.

4) Jews and Armenians coincide in their occupations and social position. They usually don't hold positions in the Army or in the Public Service, and they clearly stand out in the field of liberal professions, trade, professional activities, goldsmithing and jewellery. ${ }^{28}$ In general, the Armenian youth enjoy an education better than the rest of Syrians, speak a number of languages (Armenian, Arabic, Turkish, English and French,) and mantain ties with other Armenians in Europe and the United States. ${ }^{29}$

This first approach can serve to establish a framework to understand the Syrian stereotype of Jews: they share (or rather they shared) with Armenians many of the aforementioned peculiarities. In both cases, the attitude is very similar and it may be summarized in these three points:

1) Contrary to what is commonly supposed, the signs of animosity against the Syrian Jews or the Jews in general are very uncommon. As a general rule, Syrians speak about Jews with admiration.

2) For both Muslims and Christians, the Syrian Jews are considered, like Armenians as "passing guests" that do not interfere in the political and social affairs of the country. ${ }^{30}$

3) As a general rule, they are placed apart in the social classifications, in the same way as Christians do with Armenians.

27 See Aïda Budjikanian, "Les Arméniens du Moyen-Orient. Leur existence actuelle à la lumière du passé récent”, Les Temps Modernes 504-506 (1988), 245.

28 See Jean-Pierre Valognes, Vie et mort des Chrétiens d'Orient. Des origines à nous jours (Paris: Fayard 1994), 480-485 and 724.

${ }^{29}$ See Aïda Budjikanian, "Les Arméniens du Moyen-Orient. Leur existence actuelle à la lumière du passé récent”, 241-244.

${ }^{30}$ See Jean-Pierre Valognes, Vie et mort des Chrétiens d'Orient. Des origines à nous jours (Paris: Fayard 1994), 480-481. 


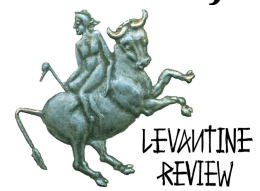

\section{THE JEWISH CHARACTER ACCORDING TO POPULAR SAYINGS, PROVERBS, AND ANECDOTES}

In Aleppo there is a proverb about the Jews that goes as follows: "the sparrows are Jews and the pigeon is Muslim" (il-'asafir yahud ul-hamameh muslimeh.) The meaning is rather clear: compared to the Muslims, the Jews are a small and weak minority that had to struggle in order to survive and thrive. The causes of the Jewish emigration is frequently related to the influence of Zionism but also to the oppresion of the Baathist regime.

Most Syrians find it remarkable that the Jews adhere to their religious institutions as the main way to define their identity and their traditional resistence to assimilation. "Coffee without tobacco is like a Jew without a rabbi" (il-ahweh bila dukhaan, mitl il-yahudi bila hakhaam) goes a popular Syrian saying. This characteristic, that is the Jews' alleged resistance to assimilation, has provoked a certain suspicion against them among their fellow citizens ("don't go with a beardless or a 'baby faced' person, and don't ask advice of a Jew," la trafi' l-ajrudi u-la tshawer il-yahudi.) In this sense, it is considered dangerous or futile to establish more than the necessary ties with the Jews ("if you praise a Jew he will think badly of you" il-yahudi iza madahto bisii' az-zann bik.) ${ }^{31}$

Many Syrians point out two main defects in Syrian Jews: superstition and interest in money. In reference to the first "defect," there is ample information about the alleged linguistic taboos present in the colloquial Arabic of Jews (some of them of religious origin and not due to superstition): the most well known resides in avoiding pronouncing sacred words or bad luck expressions and names, like Allah (God), 'Azrael (the Angel of Death or Malakh ha-mavet) or fakhm (coal.) For the Jews, it is a bad luck omen to listen to the barking of dogs (interpreted as a call to the aforementioned 'Azrael) and they hate to get close to owls: in fact, a Jewish contribution to the current dialect is the word bumeh (owl) in reference to an ugly or jinxed person, or the verb bawwam / tbawwam (to jinx, to be jinxed.) ${ }^{32}$

An element that unifies Jews and Armenians in the Syrian mentality is their rapport with money, a circumstance that could be related to their skill for business and, after all, the envy caused by their prosperity (in this sense, it would be interesting to establish a comparison with the idea of the Jews still present inside the Iberian Peninsula): the Jew always speaks about money (mustahiil timdi 'ashar da'a'i 'al-yahudi u ma yuzkur fia $m a$ 'ut, "it is impossible that a Jew spends ten minutes without mentioning the word "money,") or the ungenerous (il-yahudi sallam taba'o uma sallam, "the Jew gave something and he didn't give anything.") 33

${ }^{31}$ Quoted in Mahmud al-Haritani, Taarikh al-Yahud fi Halab (Aleppo: Ray 2008), 167, 176 and 179.

32 See Muhammad Khayr ad-Din al-Asadi, Mawsu'a, II, 200.

${ }^{33}$ In Aleppo there is a saying ma hada bbakh-kher b-balaash ("nobody burns incense for free") that it is often associated with a Jew that gave a donation to the Ottoman Government and some time after demanded a wagon of each Syrian train to transport his goods. 


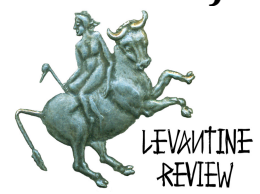

Nevertheless, Syrians also recognize the enviable virtues of the Syrian Jews: the first one is their initiative for business, their skill for trade (Be' l-yahud mitl alk il-jlud, "the sale of the Jews is like chewing leather,") and their ability to resolve hard problems: ma bi'azzel hal-jureh illa Abu Ishaq, "only Abu Ishaq can clean this hole." This Abu Ishaq of lost memory, was a Jewish taruq (a person in charge of the roads) famous for his ability to repair everything. His name remains as the perfect example of a clever person able to resolve even a disaster. But the great quality of the Syrian Jews has always been their proverbial sense of humour, often racy or even black, that is mentioned in many histories that can be heard in Aleppo or Damascus. Calling a hard-boiled egg "the hen that escaped" (jejeh tarat, or worse B'asu-a u-nhazamet,) or the fried eggplant muslim mahru' ("a burned Muslim") are both Jewish expressions. Many Syrians wistfully consider the Jewish exodus from Syria an irreparable loss for the country; a country which has been deprived of a cultural and religious tradition otherwise safeguarded during centuries by innocent fellow citizens who paid the consequences of a regional conflict not of their own making.

*Alejandra Álvarez Suárez holds a PhD in Political Science from the University of Barcelona. She is formerly Professor of Spanish Language at the University of Aleppo (Syria, 2006-2009,) and author of the recent Non-Muslim Communities in a Muslim Environment; The Survival of the Ottoman Model in Contemporary Syria (in Spanish, Madrid; CantArabia, 2013.)

**Francisco del Río Sánchez is Associate Professor in the Department of Semitic Languages at the University of Barcelona (Spain.) He has worked in Aleppo (Syria) for the past fourteen years, directing a research project cataloguing Syriac and Arabic manuscripts preserved in family collections and private libraries throughout the city. Dr. del Río Sánchez has written extensively in the field of Semitics, Arabic, and Aramaic Studies. 